\title{
The Effects of Trenbolone Supplementation on the Extremity Bones in Running Rats
}

\author{
Ali SARI, Sefa LÖK \\ Selcuk University, Faculty of Sport Science, Konya, Turkey. \\ Address Correspondence to S, Lok, e-mail: sefalok@selcuk.edu.tr
}

\begin{abstract}
Anabolic steroids are testosterone derivatives through which anabolic effects are maintained and androgenic effects are minimized. The use of ergogenic agents is increasing among athletes for doping in order to increase physical performance and change external image. The objective of this study was to determine effects of trenbolone supplement administered on running rats for 4 weeks on extremity bones. The study was conducted with 28 male Wistar rats aged 28 days with a mean weight of $61,80 \mathrm{~g}$ supplied from the Selcuk University Experimental Medical Research and Application Center. The rate were divided into 4 groups as C (Controls), E (Exercise), T (Trenbolone), and TE (trenbolone + Exercise). The trial period lasted 4 weeks. Supply, care, feeding, and experimental applications of rats were performed in the Selcuk University Experimental Medical Research and Application Center. Anterior and posterior extremities' bones were dissected and exposed, and the humerus and femur bones exposed were dried. Length, corpus thickness, cortex thickness, and medulla diameter points were determined and the necessary measures were taken. The results are expressed as mean $\pm \mathrm{SD}$. ANOVA and Duncan tests were used for the comparison of data. $\mathrm{p}<0.05$ values were considered statistically significant. The mean femoral length was found as $31.31 \pm 0.69$ in the rats in Group T, 31.46 \pm 0.72 in Group E, 31.51 \pm 0.58 in Group TE, and $31.48 \pm 0.71$ in Group C (controls). Examining the mean femoral lengths of Groups T, E, TE and C; the mean femoral length in Group T was numerically higher than that of the Groups E, TE and C, although the difference was not statistically significant (F:0.112; p:0.637). The mean humerus length was found as $24.93 \pm 0.59$ in the rats in Group T, 24.96 \pm 0.68 in Group E, 25.33 \pm 0.81 in Group TE, and 25.29 \pm 0.77 in Group C (controls). Examining the mean humerus lengths of Groups T, E, TE and C; the mean humerus length in Group T was numerically higher than that of the Groups E, TE and C, although the difference was not statistically significant (F:0.608; $\mathrm{p}: 0.355)$. We found that the mean values of corpus and cortex thickness, and medullary diameters were similar in the Groups $\mathrm{T}$, $\mathrm{E}, \mathrm{TE}$, and $\mathrm{C}$, and the differences were not statistically significant ( $\mathrm{p}>0.05)$. Results of this study indicate that trenbolone supplement may lead to early epiphyseal closure in femur and humerus bones of rats, ceasing the increase in their length. We believe that the results obtained from this trenbolone trial will provide important data to the studies that will be conducted on anabolic androgenic steroids.
\end{abstract}

Key words: Anabolic Androgenic Steroid, Trenbolone, Rat, Femur, Humerus

\section{INTRODUCTION}

In the most universal definition, doping is defined as the use, consume or illegal intake of substances prohibited under the rules in order to increase the athletic (12).

Anabolic androgenic steroids (AASs) are mostly used for their anabolic effect, and for increasing endurance and sportive performance by increasing muscle mass and muscular tissue $(2,6)$.

Frequently preferred anabolic androgenic steroid by athletes and other persons is trenbolone (20). Trenbolone hormone was produced for the first time at the end of 1960s. 19-nortestosterone (19-nor) classification shows structural variance from testosterone since it is deprived of one carbon atom. This difference provides trenbolone to be in the same category with Deca Durabolin (Nandrolone Decanoate) (14). Trenbolone is a highly potent anabolic steroid and primarily preferred by many athletes (20).

Similar to the other steroids, trenbolone significantly increases protein synthesis and nitrogen involvement in muscular tissue. Protein synthesis is rate of cell to produce proteins; protein represent primary constituent of a cell (19). Another steroid feature of trenbolone is inhibition of glucocorticoid hormones. Glucocorticoid hormones that are named as stress hormones in some sources function differently from anabolic steroids in many aspects since these hormones destroy muscular tissue and increase adipose tissue (4). 
The objective of this study was to determine effect of trenbolone supplement administered for four weeks in extremity bones of rats.

\section{MATERIAL \& METHODS}

This study was conducted on 28 rats (Male, Wistar) of 28 days $(61.80 \mathrm{~g})$ supplied from the Selcuk University Experimental Medicine Research and Application Center. The rats were divided into four group as the Control group (C), Exercise group (E), Trenbolone group $(\mathrm{T})$, and Trenbolone + Exercise group (TE). The experiments lasted for four week. Supply, care, feeding, and experimental application were conducted in the Selcuk University Experimental Medicine Research and Application Center. The rats were hosted in the experimental animals unit, in the plastic rat cages at $23 \pm 2^{\circ} \mathrm{C}$ room temperature and $50 \pm 10 \%$ relative moist environment, 12/12 light/dark cycle and with feeding ad libitum. Daily freshened water $(\sim 50$ $\mathrm{mL} /$ day/rat) was kept available in front of the rats for drinking any time. The study was approved by the Selcuk University Experimental Medicine Research and Application Center Ethical Committee (Decision no: 2018-2, Date: 24/01/2018). The animals were grouped as follows:

Group 1, C (Control) group (n:7): Rats in this group were given standard pellet feed and drinking water ad libitum.

Group 2, E (Exercise) group (n:7): Rats in this group were given standard pellet feed and drinking water ad libitum. The rats were exercised on treadmill at a rate of $25 \mathrm{~m} / \mathrm{min}, 45$ minutes a day, 5 days a week for 4 weeks.

Group 3, T (Trenbolone) group (n:7). Rats in this group were given standard pellet feed and drinking water ad libitum during the study. Trenbolone enanthate at a dose of $10 \mathrm{mg} / \mathrm{Kg} / \mathrm{rat}$ (10) was diluted in $100 \mathrm{mcl}$ peanut oil and administered as intraperitoneal one day a week for four weeks.

Group 4, TE (Trenbolone + Exercise) group (n:7). Rats in this group were given standard pellet feed and drinking water ad libitum during the study. Trenbolone enanthate at a dose of $10 \mathrm{mg} / \mathrm{Kg} / \mathrm{rat}$ (10) was diluted in $100 \mathrm{mcl}$ peanut oil and administered as intraperitoneal one hour before the exercise, one day a week. The rats in this group were exercised for four week.

Trenbolone Supplement: Trenbolone enanthate (TRENBOLONE E200, Pharma Generics) at a dose of $10 \mathrm{mg} / \mathrm{Kg} / \mathrm{rat}$ was diluted in $100 \mathrm{mcl}$ peanut oil and administered as intraperitoneal in rats in the groups
$\mathrm{T}$ (Trenbolone) and TE (Trenbolone + Exercise) for four weeks. Body weight of the rats was measured at the beginning of the study and on the same day during 4 weeks to adjust the weekly dosage (10 $\mathrm{mg} / \mathrm{Kg} / \mathrm{rat}$ ) for trenbolone administration.

Exercise Program: 8-track treadmill, specially designed for rats was used in exercise application. After an adaptation period of one week (5 days), rats in the exercise groups were exercised on the treadmill at a rate of $25 \mathrm{~m} / \mathrm{min}(1.5 \mathrm{Km} /$ hour $)$ for 45 minutes, 5 days a week over 4 weeks.

\section{Adaptation protocol:}

Day 1: $10 \mathrm{~m} / \mathrm{min}, 10$ minutes

Day 2: $20 \mathrm{~m} / \mathrm{min}, 10$ minutes

Day 3: $25 \mathrm{~m} / \mathrm{min}, 10$ minutes

Day 4: $25 \mathrm{~m} / \mathrm{min}, 20$ minutes

Day 5: $25 \mathrm{~m} / \mathrm{min}, 30$ minutes

Measurements: At the end of the study, front and back extremities of the subjects were exposed and dissected. Length, corpus thickness, cortex-cortical bone thickness and medullary diameter-cavum medullare measurements were carried out in the exposed humerus and femur bones, using a 0-100 mm caliper.

Anatomic reference points [A (length), B (corpus), C1-C2 (cortex-cortical bone thicknesssubstantia compacta) and D (medullary diametercavum medullare)] of the humerus and femur bones at the right side to be measured were determined and the necessary measurements were made in each of these points with a $0-100 \mathrm{~mm}$ caliper (Stainless hardened digital caliper, China) (Images 1, 2).

Status of epiphysis was examined in the relevant bones. Images of the bones were taken with a digital camera (Nikon D200, China) (Images 1, 2). In addition, final mean body weight was measured in all subjects with a precision scale before euthanasia.

Statistical Analysis: Statistical evaluation of the data was performed utilizing SPSS 18.0 (SPSS 18.0 for Windows/SPSS Inc, Chicago, USA). The results were expressed as mean \pm standard deviation. Comparison of the data between the groups was made using ANOVA and Duncan tests. $\mathrm{p}<0.05$ values were considered statistically significant. Image 1. Reference points of length (A), Corpus $(\mathrm{B} 1+\mathrm{B} 2 / 2)$, Cortex $(\mathrm{C} 1+\mathrm{C} 2+\mathrm{C} 3+\mathrm{C} 4 / 4)$ and medullary diameters $(\mathrm{D} 1+\mathrm{D} 2 / 2)$ of humerus of the rats (Right medial side) 
diameters $(\mathrm{D} 1+\mathrm{D} 2 / 2)$ of femur of the rats (Right medial side)
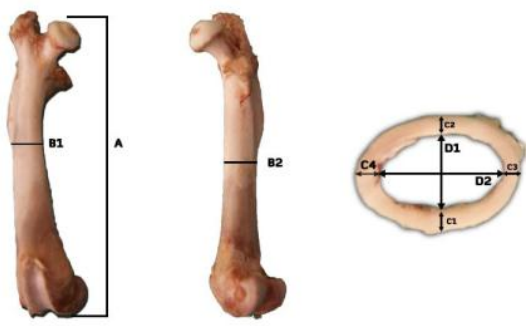

A: Distance between the end points of caput humeri and trochlea humeri

B: Corpus thickness of the humerus (lower border level of Tuberositas deltoidea)

C1-C2: Mean femur thickness of the humerus at cortex level (cortical bone-substantia compacta)

D: Cavum medullare diameter of the humerus at cortex level

Image 2. Reference points of length (A), Corpus $(\mathrm{B} 1+\mathrm{B} 2 / 2)$, Cortex $(\mathrm{C} 1+\mathrm{C} 2+\mathrm{C} 3+\mathrm{C} 4 / 4)$ and medullary
A: Distance between the end points of caput ossis femoris and trochlea ossis femoris

B: Corpus thickness of the femur (lower border level of Trochanter tertius)

C1-C2: Mean femur thickness of the femur at cortex level (cortical bone-substantia compacta)

D: Cavum medullare diameter of the femur at cortex level

\section{RESULT}

Table 1. Comparison of the mean length, and diameters of corpus, cortex and medullary of femur bones in (Trenbolone), E (Exercise), TE (Trenbolone + Exercise) and C (Control) groups (mm) (mean \pm SD).

\begin{tabular}{|c|c|c|c|c|c|}
\hline & $T$ & E & TE & C & Test value, $p$ \\
\hline Length & $31.31 \pm 0.69$ a & $31.46 \pm 0.72^{a}$ & $31.51 \pm 0.58^{\text {a }}$ & $31.48 \pm 0.71$ a & F: 0.112 p:0.637 \\
\hline Corpus & $3.74 \pm 0.15^{\mathrm{a}}$ & $3.76 \pm 0.18^{\mathrm{a}}$ & $3.92 \pm 0.13^{a}$ & $3.74 \pm 0.15$ & F: 2.797 p:0.062 \\
\hline Cortex & $0.614 \pm 0.04 \mathrm{a}$ & $0.605 \pm 0.03^{a}$ & $0.612 \pm 0.04^{a}$ & $0.610 \pm 0.05$ a & F: 0.043 p:0.988 \\
\hline Medullary & $1.987 \pm 0.14$ a & $2.135 \pm 0.20^{a}$ & $2.125 \pm 0.12^{\mathrm{a}}$ & $1.975 \pm 0.21$ a & F: 1.811 p:0.172 \\
\hline
\end{tabular}

The mean femur length of the rats was found as $31.31 \pm 0.69$ in Group $T, 31.46 \pm 0.72$ in Group E, $31.51 \pm 0.58$ in Group TE, and 31.48 \pm 0.71 in Group C. When the mean femur length values of the Groups T, E, TE and C were examined; the mean length was numerically shorter in Group $T$ compared to Groups E, TE, and C, although the difference was not statistically significant (F:0.112, $\mathrm{p}: 0.637)$.

The mean femur corpus thickness of the rats was found as $3.74 \pm 0.15$ in Group T, 3.76 \pm 0.18 in Group E, 3.92 \pm 0.13 in Group TE and $3.74 \pm 0.15$ in Group C. When the mean femur corpus thickness values were evaluated; it was found that the mean femur corpus thickness was similar among all groups and no statistically significant difference was found between them (F: 2.797, p: 0.062).
The mean femur cortex thickness of the rats was found as $0.614 \pm 0.04$ in Group T, $0.605 \pm 0.03$ in Group E, $0.612 \pm 0.04$ in Group TE and $0.610 \pm 0.05$ in Group C. When the mean femur cortex thickness values were evaluated; it was found that the mean femur cortex thickness was similar among all groups and no statistically significant difference was found between them (F:0.043, p:0.988).

The mean femur medullary diameter of the rats was found as $1.987 \pm 0.14$ in Group T, $2.135 \pm 0.20$ in Group E, 2.125 \pm 0.12 in Group TE and $1.975 \pm 0.21$ in Group C. When the mean femur medullary diameter values were evaluated; it was found that the mean femur medullary diameter was similar among all groups and no statistically significant difference was found between them (F:1.811, $\mathrm{p}: 0.172)$ 
Table 2. Comparison of the mean length, and diameters of corpus, cortex and medullary of humerus bones in (Trenbolone), E (Exercise), TE (Trenbolone + Exercise) and C (Control) groups (mm) (mean \pm SD).

\begin{tabular}{|c|c|c|c|c|c|}
\hline & $\mathrm{T}$ & $\mathrm{E}$ & TE & C & Test value, $p$ \\
\hline Length & $24.93 \pm 0.59 \mathrm{a}$ & $24.96 \pm 0.68 \mathrm{a}$ & $25.33 \pm 0.81 \mathrm{a}$ & $25.29 \pm 0.77 \mathrm{a}$ & F:0.608 p:0.355 \\
\hline Corpus & $2.47 \pm 0.06 \mathrm{a}$ & $2.51 \pm 0.12 \mathrm{a}$ & $2.52 \pm 0.13 \mathrm{a}$ & $2.46 \pm 0.07 \mathrm{a}$ & $\mathrm{F}: 0.496 \mathrm{p}: 0.689$ \\
\hline Cortex & $0.594 \pm 0.06 \mathrm{a}$ & $0.591 \pm 0.03 \mathrm{a}$ & $0.594 \pm 0.06 \mathrm{a}$ & $0.595 \pm 0.02 \mathrm{a}$ & F:0.013 p:0.998 \\
\hline Medullary & $1.512 \pm 0.12 \mathrm{a}$ & $1.723 \pm 0.14 \mathrm{a}$ & $1.714 \pm 0.21 \mathrm{a}$ & $1.524 \pm 0.18 \mathrm{a}$ & F:0.246 p:0.652 \\
\hline
\end{tabular}

The mean humerus length of the rats was found as $24.93 \pm 0.59$ in Group T, $24.96 \pm 0.68$ in Group E, $25.33 \pm 0.81$ in Group TE, and 25.29 \pm 0.77 in Group C. When the mean femur length values of the Groups $\mathrm{T}, \mathrm{E}, \mathrm{TE}$ and $\mathrm{C}$ were examined; the mean humerus length was numerically shorter in Group $\mathrm{T}$ compared to Groups E, TE, and C, although the difference was not statistically significant (F:0.608, p:0.355).

The mean humerus corpus thickness of the rats was found as $2.47 \pm 0.06$ in Group T, 2.51 \pm 0.12 in Group E, 2.52 \pm 0.13 in Group TE and 2.46 \pm 0.07 in Group C. When the mean humerus corpus thickness values were evaluated; it was found that the mean humerus corpus thickness was similar among all groups and no statistically significant difference was found between them (F:0.496, p:0.689).

\section{DISCUSSION}

When femur and humerus lengths of Groups T (Trenbolone), E (Exercise), TE (Trenbolone + Exercise) and C (Control) were examined; the mean femur length was numerically shorter in Group $\mathrm{T}$ than Groups E, TE, and C, although the difference was not statistically significant ( $p>0.05)$.

Studies conducted on experimental animals have reported many side effects of AASs $(1,3,8,13$, $15,17,21)$.

In a study investigating effects of trenbolone application on the urinary system, it was concluded that trenbolone application has a partial effect on the urinary system in experimental group (9).

In a study examining effects of trenbolone administered at different time periods and different doses on female rats, trenbolone was found to cause an increase in density of amniotic fluid in pregnant rats (8).

In a study evaluating effects of trenbolone application on muscles, bones, adipose tissue and hemoglobin levels of rats, it was concluded that
The mean humerus cortex thickness of the rats was found as $0.594 \pm 0.06$ in Group T, $0.591 \pm 0.03$ in Group E, $0.594 \pm 0.06$ in Group TE and $0.595 \pm 0.02$ in Group C. When the mean humerus cortex thickness values were evaluated; it was found that the mean humerus cortex thickness was similar among all groups and no statistically significant difference was found between them (F:0.013, p:0.988).

The mean humerus medullary diameter of the rats was found as $1.512 \pm 0.12$ in Group $\mathrm{T}$, $1.723 \pm 0.14$ in Group E, $1.714 \pm 0.21$ in Group TE and $1.524 \pm 0.18$ in Group C. When the mean humerus medullary diameter values were evaluated; it was found that the mean humerus medullary diameter was similar among all groups and no statistically significant difference was found between them (F:0.246, p:0.652).

trenbolone increased density of muscle and bone tissues (16).

In a study investigating effect of trenbolone on bone mineral density, intramuscular trenbolone application was found to increase bone mineral density without changing hemoglobin density (11).

In another study investigating effects of exercise plus nandrolone supplement on heart muscle of rats, it was reported that heart muscle of the rats administered nandrolone supplement was damaged (7).

In a study in which rats were given AAS for 15 days and effects of AAS in cognitive function of rats were investigated, it was reported that rats in AAS group developed learning and memory disorder (18).

In a study examining effect of trenbolone and testosterone supplement on skeletal muscle growth of rats, it was concluded that testosterone grew skeletal muscle at a higher rate than trenbolone (22). 
In a study investigating effects of androgen application on bones of rats, it was reported that femur bones of the rats given androgen remained short (5).

In the present study, when corpus and cortex thickness and medullary diameter values of femur and humerus were examined in $\mathrm{T}$ (Trenbolone), E (Exercise), TE (Trenbolone + Exercise) and C (Control) groups; corpus and cortex thickness and medullary diameter values of femur and humerus were similar between Groups T, E, TE and $C(p>0.05)$.

\section{CONCLUSION}

Femur length was shorter in the rats in Group T compared to the rats in Groups E, TE and C after trenbolone supplement.

\section{REFERENCES}

1. Al-Kennany ER, Al-Hamdany EK. Pathological effects of anabolic steroid (Sustanon ${ }^{\circledR}$ ) on liver of male rats. Iraqi Journal of Veterinary Sciences, 2014; 28(1), 31-9.

2. Dallı M, Işıkdemir E, Bingöl E. Determination of Doping Knowledge Level of Physical Education and Sports College Students. International Journal of Science Culture and Sport (IntJSCS), 2014; 2(6), 11-20.

3. Frankenfeld SP, de Oliveira LP, Ignacio DL, Coelho RG, Mattos MN, Ferreira ACF, Fortunato RS. Nandrolone decanoate inhibits gluconeogenesis and decreases fasting glucose in Wistar male rats. Journal of Endocrinology, 2014; 220(2), 143-53.

4. Garmyn AJ, Miller MF. Meat science and muscle biology symposium-Implant and beta agonist impacts on beef palatability. Journal of animal science 2014; 92.1, 10-20.

5. Haffner-Luntzer M, Kovtun A, Lackner I, Mödinger $\mathrm{Y}$, Hacker S, Liedert A, Ignatius A. Estrogen receptor $\alpha$-(ER $\alpha)$, but not ER $\beta$-signaling, is crucially involved in mechanostimulation of bone fracture healing by whole-body vibration. Bone, 2018; 110, 11-20.

6. Hartgens F, Kuipers H. Effects of androgenic-anabolic steroids in athletes. Sports medicine, 2004; 34(8), 513-54.

7. Hassan AF, Kamal MM. Effect of exercise training and anabolic androgenic steroids on hemodynamics, glycogen content, angiogenesis and apoptosis of cardiac muscle in adult male rats. Int J Health Sci, 2013; 7(1), 47-60.

8. Hotchkiss AK, Furr J, Makynen EA, Ankley GT, Gray Jr LE. In utero exposure to the environmental androgen trenbolone masculinizes female Sprague-Dawley rats. Toxicology letters, 2007; 174(1-3), 31-41.

9. Jensen KM, Makynen EA, Kahl MD, Ankley GT. Effects of the feedlot contaminant $17 \alpha$-trenbolone on reproductive endocrinology of the fathead minnow. Environmental science \& technology, 2006; 40(9), 3112-7.
Humerus length was shorter in the rats in Group T compared to the rats in Groups E, TE and C after trenbolone supplement.

Although the results were not statistically significant for both measurements, looking to the numerical values of humerus and femur bones among the groups, remarkably the shortest measurement was in the trenbolone group.

As it will be understood from the result of this study, it can be said that trenbolone supplement will lead to the cessation of growth in humerus bone and early epiphyseal closure.

\section{ACKNOWLEDGEMENTS}

This study is a portion of master thesis and is supported by Selcuk University Scientific Research Projects Coordinator (SUBAPK, 18202009)

10. Lok S. Does the use of Testosterone Enanthate as a Form of Doping in Sports Cause Early Closure of Epiphyseal in Bones?. Int. J. Morphol, 2015; 33(4), 1201-4.

11. McCoy SC, Yarrow JF, Conover CF, Borsa PA, Tillman MD, Conrad BP, Ye F. 17ß-Hydroxyestra-4, 9, 11-trien-3-one (Trenbolone) preserves bone mineral density in skeletally mature orchiectomized rats without prostate enlargement. Bone, 2012; 51(4), 667-73.

12. Müller RK, 2010. History of doping and doping control. In Doping in sports: Biochemical principles, effects and analysis(pp. 1-23). Springer, Berlin, Heidelberg.

13. Naraghi MA, Abolhasani F, Kashani I, Anarkooli IJ, Hemadi M, Azami A, Barbarestani M, Aitken RJ, Shokri S. The effects of swimming exercise and supraphysiological doses of nandrolone decanoate on the testis in adult male rats: a transmission electron microscope study. Folia Morphol, 2010; 69(3), 138-46.

14. Norris DO, James AC, 2005. Endocrine disruption: biological bases for health effects in wildlife and humans. Oxford University Press,

15. Rocha FL, Carmo EC, Roque FR, Hashimoto NY, Rossoni LV, Frimm C, Ane'as I, Negra'o CE, Krieger JE, Oliveira EM. Anabolic steroids induce cardiac renin-angiotens in system and impair the beneficial effects of aerobic training in rats. Am J Physiol Heart Circ Physiol, 2007; 293(6), 3575-83.

16. Santillana JM, Cannady DF, VanPelt TD, Sanchez J, Bryan $P$, Conrad JE, Yarrow JF, 2011. 17 $\beta$-hydroxyestra-4, 9, 11-trien-3one (Trenbolone) Exhibits Tissue Selective Anabolic 1 Activity: Effects on Muscle, Bone, Adiposity, Hemoglobin, and Prostate 2.

17. Shokri S, Hemadi M, Bayat G, Bahmanzadeh M, JafariAnarkooli I, Mashkani B. Combination of running exercise and high dose of anabolic androgenic steroid, nandrolone decanoate, increasesprotamine deficiency and DNA damage in rat spermatozoa. Andrologia, 2014; 46(2), 184-90.

18. Tanehkar F, Rashidy-Pour A, Vafaei AA, Sameni HR, Haghighi S, Miladi-Gorji H, Bavarsad K. Voluntary exercise 
does not ameliorate spatial learning and memory deficits induced by chronic administration of nandrolone decanoate in rats. Hormones and behavior, 2013; 63, 158-65.

19. Villeneuve DL, Jensen KM, Cavallin JE, Durhan, EJ, Garcia-Reyero N, Kahl MD, Ankley GT. Effects of the antimicrobial contaminant triclocarban, and co-exposure with the androgen $17 \beta$-trenbolone, on reproductive function and ovarian transcriptome of the fathead minnow (Pimephales promelas). Environmental toxicology and chemistry, 2017; 36(1), 231-42.

20. Wijayanti AD, Widiasih DA, Susetya H, Yudhabuntara $D$, Drastini Y, Primatika RA, Santosa WI, 2017. Detection of
Trenbolone Acetate in Beef Muscle and Liver Using HighPerformance Liquid Chromatography Method. In Proceeding of the 1st International Conference on Tropical Agriculture (pp. 527-32). Springer, Cham.

21. Yarrow JF, Conover CF, Beggs LA, Beck DT, Otzel DM, Balaez A, Neuville KG. Testosterone dose dependently prevents bone and muscle loss in rodents after spinal cord injury. Journal of neurotrauma, 2014; 31(9), 834-45.

22. Ye F, McCoy SC, Ross HH, Bernardo JA, Beharry AW, Senf SM, Smith BK. Transcriptional regulation of myotrophic actions by testosterone and trenbolone on androgenresponsive muscle. Steroids, 2014; 87, 59-66. 